\title{
Genetic Relatedness among Guinea Fowl (Numida meleagris) and Other Poultry Species based on Sequence Homology in Interleukin-6 (IL-6) gene
}

\author{
G. Goyal ${ }^{1,2 *}$, V. Upmanyu ${ }^{3}$, S. Shukla ${ }^{2}$, S. Mehra ${ }^{2}$, S. K. Singh²,

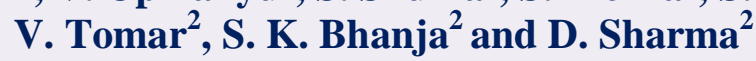 \\ ${ }^{1}$ Department of Poultry Science, College of Veterinary Science \& Animal Husbandry, \\ Nanaji Deshmukh Veterinary Science University, Jabalpur-482001, M.P., India \\ ${ }^{2}$ Central Avian Research Institute, Izatnagar-243122, Bareilly, U.P., India \\ ${ }^{3}$ Indian Veterinary Research Institute, Izatnagar-243122, Bareilly, U.P., India \\ *Corresponding author
}

\section{A B S T R A C T}

\begin{tabular}{|l|}
\hline Ke y w or d s \\
$\begin{array}{l}\text { Guinea fowl, } \\
\text { Interleukin-6, } \\
\text { Nucleotide } \\
\text { sequence, Amino } \\
\text { acid sequence }\end{array}$ \\
\hline Article Info \\
\hline $\begin{array}{l}\text { Accepted: } \\
\text { 20 December } 2020 \\
\text { Available Online: } \\
\text { 10 January } 2021\end{array}$ \\
\hline
\end{tabular}

Interleukin-6 (IL-6) is a multifunctional pro-inflammatory cytokine that plays a major role in regulating immune responses, acute phase reactions and haematopoiesis. IL-6 is produced by different cell types and acts on B cells, T cells, hepatocytes, haematopoietic progenitor cells and cells of the central nervous system. In this study the partial complementary DNA sequence (CDS) fragment of 219 bp of IL-6 gene of guinea fowl (Numidam eleagris) was PCR amplified, cloned and sequenced. This was the first report of sequencing and characterization of the IL-6 gene of guinea fowl. The nucleotide sequence (NCBI GenBank Accession No HQ258968) of IL-6 was compared for sequence homology with related sequences from different poultry species, retrieved from Genbank database and the per cent genetic similarity and genetic divergence were estimated using Megalign programme of DNASTAR software. Guinea fowl showed higher per cent identity (96.6\%) with chicken in comparison to per cent identity (90.8\%) with that of duck. The per cent identity between chicken and duck was comparatively less $(88.5 \%)$. Likewise the IL-6 gene of duck showed low per cent divergence $(9.2 \%)$ with guinea fowl in comparison to chicken IL-6 gene (11.5\%). The phylogenetic analysis revealed that chicken and guinea fowl were clustered together and separated from the duck. These results suggested that guinea fowl showed high genetic similarity with chicken in comparison to duck. However, duck is evolutionary closer to guinea fowl then chicken.

\section{Introduction}

Interleukin-6 (IL-6) is a multifunctional cytokine that plays a major role in regulating immune responses, acute phase reactions and haematopoiesis (Kishimoto et al., 1995). IL-6 is produced by many different cell types and acts on B cells (Hirano et al., 1986), T cells (Houssiau et al., 1988), hepatocytes (Gauldie et al., 1987), haematopoietic progenitor cells (Ikebuchi et al., 1987) and cells of the central nervous system (Satoh et al., 1988). Its 
multifunctional nature is reflected in the variety of names that were originally assigned to IL-6, such as B cell differentiation factor (BCDF) (Okada et al., 1983), interferon- $\beta 2$

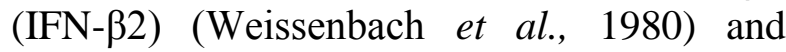
hepatocyte stimulating factor (Andus et al., 1987).

Suppression subtractive hybridization technology was used by Schneider et al., (2001) to identify differentially expressed genes in spleens of chickens that had been treated with the synthetic immune modifier S28463. One induced chicken gene encoded a protein with about $35 \%$ sequence identity to human interleukin-6 (IL-6). It consists of 241 amino acids including a putative $\mathrm{N}$-terminal signal peptide of 47 residues.

The gene encoding the chicken proinflammatory cytokine interleukin IL-6 was cloned, sequenced and mapped by Kaiser et al., (2004). Theexon:intron structure of chicken IL-6 differs from those of mammalian IL-6, as chicken having one exon fewer since the first two exons present in mammalian IL-6 genes appear to be fused in the chicken gene.

In the current study, IL-6 gene of guinea fowl was characterized first time globally. We analysed the coding region sequence of guinea fowl IL-6 gene to elucidate its role to impart better disease tolerance capacity to the guinea fowl since in many disease conditions IL-6 gene has been shown to play a significant role.

\section{Materials and Methods}

\section{Experimental birds}

A closed flock population of guinea fowl was reared at experimental guinea fowl farm of Central Avian Research Institute, Izatnagar. The study was approved by the Institutional
Animal Ethics Committee. Each Guinea fowl keet was wing banded at the time of hatching for identification of pedigree. The keets were maintained separately on deep litter system in brooder houses up to the age of 5 weeks. Thereafter, they were shifted to grower and layer houses and reared under uniform husbandry conditions.

All birds were offered ad libitum water and ration with a constant $14 \mathrm{hr}$ light per day throughout the experiment. The layers were used for production of Guinea fowl keets used in the current study.

\section{Bacterial strain}

A Nalidixic acid resistant strain of Salmonella enterica serovar Enteritidiswas procured from National Salmonella Centre, Indian Veterinary Research Institute, Izatnagar. Salmonella enterica serovar Enteritidis inoculum was prepared by inoculation of procured culture into Brain Heart Infusion broths (BHI) and incubated aerobically at $37^{\circ} \mathrm{C}$ for $16-18 \mathrm{hrs}$. The bacterial growth on $\mathrm{BHI}$ broths were harvested by centrifugation at $8000 \mathrm{rpm}$ for $15 \mathrm{~min}$ and washed twice with Phosphate Buffered Saline by centrifugation at $8000 \mathrm{rpm}$ for $15 \mathrm{~min}$. The bacterial suspension was pipetted out and concentration of bacteria was determined by turbidimetry method $(560 \mathrm{~nm})$.

The working bacterial suspension containing $10^{8}$ bacterial cells/ml was obtained by adjusting the dilution with normal saline solution. In the present study, the dose (final concentration) of Salmonella enterica serovar Enteritidis $10^{6}$ cells/well (live bacteria) was chosen as per earlier reports available in literature. For applying the ascertained number of cells per well a concentration of $10^{8}$ cells $/ \mathrm{ml}$ was prepared in sterile PBS and $10 \mu 1$ of this was used for induction in each well. 


\section{Peripheral blood mononuclear cells (PBMCs) culture}

Approximately $3 \mathrm{ml}$ of heparinized blood from individual bird was collected from Jugular vein under sterile conditions. Three milliliter of Histopaque-1077 (Sigma Diagnostics Inc., St. Louis, MO, USA) was added to $15 \mathrm{ml}$ conical centrifuge tube at room temperature and $3 \mathrm{ml}$ of whole blood was carefully layered over the column and centrifuged at $1700 \mathrm{rpm}(900 \mathrm{x} \mathrm{g})$ for $30 \mathrm{~min}$ at room temperature. After centrifugation, the opaque inter-phase containing mononuclear cells was carefully aspirated with a micropipette. The upper layer was discarded.

The opaque inter-phase was carefully transferred to a clean centrifuge tube and equal volume of ice chilled DEPC treated isotonic PBS solution was added and mixed gently, then centrifuged at $3000 \mathrm{rpm}(1400 \mathrm{x}$ g) for 10 minutes. The supernatant was discarded and cell pellet was re-suspended in equal volume of ice chilled DEPC treated isotonic PBS solution and centrifuged in 3000 rpm $(1400 \mathrm{x} \mathrm{g})$ for 10 minutes. This step was repeated two times and the cell pellet suspended finally in $0.5 \mathrm{ml}$ of RPMI- 1640 medium containing 10\% FCS. Viability of these cells was assessed using trypan blue staining and the cells were counted in a hemocytometer and the concentration adjusted to $10^{6}$ cells per $\mathrm{ml}$ in RPMI- 1640 medium (Sigma Diagnostics Inc., St. Louis, MO, USA).

The PBMCs suspended in RPMI-1640 medium supplemented with $10 \%$ FCS, were plated in 6 well tissue culture plate (106 cells per well) and induced with Salmonella enterica serovar Enteritidis (106 CFU per well). The Plate was incubated under 5\% CO2 tension in humidified atmosphere for two hour at $37^{\circ} \mathrm{C}$ in a $\mathrm{CO} 2$ incubator.

\section{Total RNA isolation and cDNA synthesis}

Induced PBMCs were harvested by low-speed centrifugation after $1 \mathrm{hr}$ induction period. Total RNA was isolated from harvested cells using the Trizol reagent (Invitrogen) according to manufacturer's instructions. Concentrations and purities of RNA preparations were determined spectrophotometrically (Nanodrop, Thermo Inc.) using absorbance at 260 and $280 \mathrm{~nm}$. The A260/A280 ratio of the samples was $>1.8$. To confirm the integrity of the RNA and assess possible DNA contamination, $4 \mu \mathrm{l}$ of total RNA sample was electrophoresed on agarose gel, containing formaldehyde (Sambrooket al., 1989) and visualized by ethidium bromide staining. Possible traces of genomic DNA were removed by treating $5 \mu \mathrm{g}$ of RNA sample with $5 \mathrm{U}$ of RNase-free DNase at $37{ }^{\circ} \mathrm{C}$ for $1 \mathrm{~h}$. DNase was subsequently inactivated by inoculation at 65 ${ }^{\circ} \mathrm{C}$ for $10 \mathrm{~min}$. DNase-treated total RNA sample $(3 \mu \mathrm{g})$ was reverse-transcribed using the RevertAid first strand cDNA synthesis kit (MBI Fermentas, Hanover, MD, USA) according to manufaturer's instructions. Negative controls were performed using all components, but without added reverse transcriptase. The resultant cDNA was stored frozen at $-20{ }^{\circ} \mathrm{C}$.

\section{PCR amplification of the IL-6cDNA}

Complete coding region of IL-6 gene was amplified using a pair of gene specific primer. PCR amplification was carried out in $25 \mu 1$ volume containing $1 \mathrm{X}$ PCR buffer, 1.5 unit of Taq DNA polymerase, $1.5 \mathrm{mM} \mathrm{MgCl} 2,200$ mMdNTPs (Promega); 20 pmol of each pair of gene specific primers and $1 \mu \mathrm{l}$ of the reverse transcription product. Amplification was carried out in a thermal cycler (iCycler, BioRad, Hercules, CA) for 35 cycles with the following conditions: initial denaturation at $94{ }^{\circ} \mathrm{C}$ for $10 \mathrm{~min}$, denaturation at $94{ }^{\circ} \mathrm{C}$ for 30 
sec, annealing at $56^{\circ} \mathrm{C}$ for $45 \mathrm{sec}$ and extension at $72^{\circ} \mathrm{C}$ for $1 \mathrm{~min}$ and a final extension at $72^{\circ} \mathrm{C}$ for $10 \mathrm{~min}$. The amplification products were separated on a $1.6 \%$ TBE agarose gel and visualized by ethidium bromide staining (Fig.1).The PCR products were purified from gel using QIAquick Gel Extraction Kit (QIAGEN Inc. Valencia, CA, USA).

\section{Cloning of the purified PCR products}

The gel purified PCR products were cloned into PGEM ${ }^{\circledR}$ Teasy (Promega, USA) cloning vector. The 100ng purified PCR product was ligated with T/A cloning vector plasmid using T4 DNA Ligase enzyme according to manufacturer's instructions. Freshly prepared competent DH5 $\alpha$ (E. coli) cells were transformed with the ligated DNA. The Transformed cells were then plated on LB/Amp/X-gal/IPTG plates and incubated overnight at $37^{\circ} \mathrm{C}$.

The positive recombinant clones were identified from the transformed bacterial colonies using blue and white selection. Further, the presence of the insert was confirmed by restriction digestion with EcoRI and PCR amplification of insert using recombinant plasmid as a template.

\section{Sequence analysis}

The positive clones were sequenced commercially by automated sequencer using standard cycle conditions by Sanger's dideoxy chain termination method with standard sequencing primers (viz., T7 and SP6). Obtained sequence of IL-6gene (cDNA) was subjected to BLAST analysis (www.ncbi.nlm.nih.gov/Blast) to ascertain whether the obtained sequence was of IL-6. The nucleotide as well as deduced amino acid sequence of IL-6 gene of guinea fowl was aligned with those of other avian species available in the GenBank database using Clustal method of MegAlign programme of Lasergene software (DNASTAR, USA).

\section{Results and Discussion}

\section{Genetic similarity of guinea fowl with other avian/ mammalian species}

IL-6gene of guinea fowl was PCR amplified from Salmonella entericaserovar Enteritidis induced PBMCs, cloned and sequenced (Accession No. EU000564). The nucleotide and predicted amino acid sequences of guinea fowl and other avian species were aligned. The identity of guinea fowl with other avian species was estimated on the basis of the nucleotide sequence similarity (predicted amino acid sequence similarity) in IL-6gene of guinea fowl and other avian species (Fig. 2 \& 3). Guinea fowl showed $96.5 \%$ (91.7\%) identity with galliformes viz., chicken and Indian red jungle fowl. Guinea fowl was found $90.7 \% \quad(89.3 \%)$ identical with anseriformes viz., duck. Zebra finch showed $81.3 \%$ (78.3\%) identity with guinea fowl.

\section{Phylogenetic analysis}

Phylogenetic analysis was done on the basis of IL-6 predicted amino acid sequences to determine the evolutionary relationship of the guinea fowl with other avian species (Fig. 4). The phylogenetic tree revealed that chicken and Indian red jungle fowl together formed one arm of a cluster and guinea fowl formed another arm of this cluster. Zebra finch was placed as an arm of a cluster with chickens, Indian red jungle fowl and guinea fowl.

Schneider et al., (2001) used suppression subtractive hybridization technology to identify differentially expressed genes in spleens of chickens that had been treated with the synthetic immune modifier S-28463. Likewise, in the present study guinea fowl 
PBMCs were induced with immno-inducer e.g. SE (LPS) resulted in expression of the IL6 mRNA, which were isolated and reverse transcribed. The partial CDS of GF IL-6 gene was cloned and sequenced. This was the first report of cloning and sequencing of GF IL-6. These results are suggestive that Gf IL-6 may have similar induction kinetics as shown by the chicken IL-6.

Fig.1 Lane 1: IL-6 Gene specific PCR product; 2: Recombinant plasmid; 3: Plasmid PCR; 4: Restriction enzyme digestion of recombinant plasmid

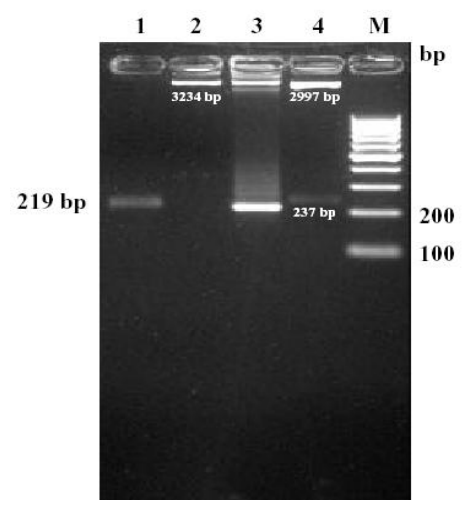

Fig.2 Percentage identity and divergence of nucleotide sequence of CDS of Guinea fowl IL-6 gene with those of its avian homologue as demonstrated by pairwise comparisons of the homologous protein-encoding regions

\begin{tabular}{|c|c|c|c|c|c|c|c|}
\hline \multicolumn{7}{|c|}{ Percent Identity } & \multirow{7}{*}{$\begin{array}{l}\text { Chicken(HM367074) } \\
\text { Duck(AB191038) } \\
\text { Guinea Fowl(HO258968) } \\
\text { Red Jungle Fowl(HM179640) } \\
\text { Zebra Finch(XM_002191284) }\end{array}$} \\
\hline \multirow{7}{*}{$\frac{4}{5}$} & 1 & 2 & 3 & 4 & 5 & & \\
\hline & & 88.4 & 96.5 & 100.0 & 84.2 & 1 & \\
\hline & 11.4 & & 90.7 & 88.4 & 77.9 & 2 & \\
\hline & 3.6 & 8.7 & & 96.5 & 81.3 & 3 & \\
\hline & 0.0 & 11.4 & 3.6 & & 84.2 & 4 & \\
\hline & 14.2 & 21.0 & 17.0 & 14.2 & & 5 & \\
\hline & 1 & 2 & 3 & 4 & 5 & & \\
\hline
\end{tabular}

Fig.3 Percentage identity and divergence of predicted amino acid sequence of Guinea fowl IL-6 gene with those of its avian homologue as demonstrated by pairwise comparisons of the homologous deduced proteins

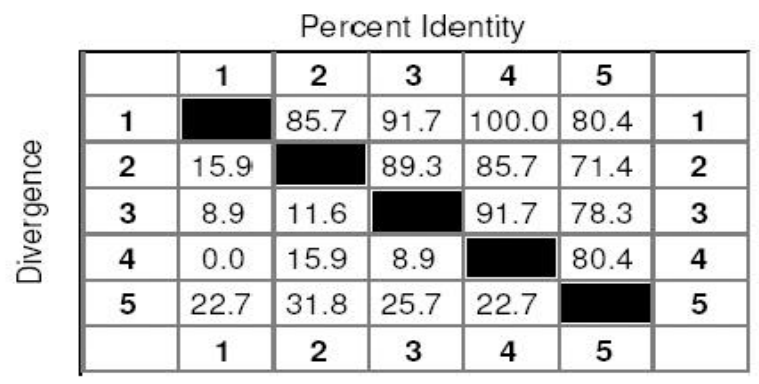

Chicken(HM367074)

Duck(AB191038)

Guinea Fowl(HQ258968)

Red Jungle Fowl(HM179640)

Zebra Finch(XM_002191284) 
Fig.4 Phylogenetic tree constructed based on the predicted amino acid sequences of CDS of IL-6 gene. For the branch lengths, the distance given in the scale represents 0.01 amino acid substitution/site. The numbers on the branches are bootstrap values

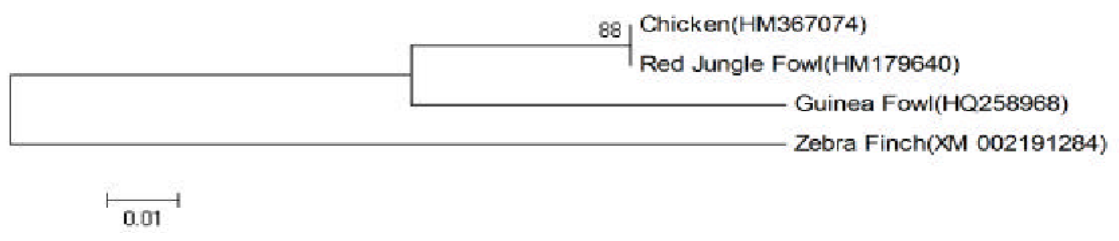

The identity of guinea fowl with other galliformes species was significantly higher than anseriformes and zebra finch. The phylogenetic tree showed the similar trends. These results are suggestive that all galliformes are evolved from a single lineage during speciation in the evolutionary development. The sequence comparison between guinea fowl and other avian species is suggestive of polymorphism between guinea fowl and other avian species, which may be the contributory factor in the disease resistance abilities of the GF, as earlier reported that in mammals, IL-6 gene promoter polymorphisms were linked to disease resistance/susceptibility profiles (Foster et al., 2000).

\section{Acknowledgement}

We gratefully acknowledge the ICAR, New Delhi and CARI, Izatnagar for providing the financial assistance and infrastructure supports to carry out the present study.

\section{References}

Andus, T., Geiger, T., Hirano, T., Northoff, H., Ganter, U., Bauer, J., Kishimoto, T.and Heinrich, P.C. 1987. Recombinant human B cell stimulatory factor 2 (BSF-2/IFN-beta 2) regulates beta-fibrinogen and albumin mRNA levels in Fao-9 cells. FEBS Lett. 221: $18-22$.

Foster, C.B., Lehrnbecher, T. and Samuels, S. 2000. An IL6 promoter polymorphism is associated with a lifetime risk of development of Kaposi sarcoma in men infected with human immunodeficiency virus. Blood, 96: 2562-2567.

Gauldie, J., Richards, C., Harnish, D., Lansdorp, P. and Baumann, H. 1987. Interferon beta 2/B-cell stimulatory factor type 2 shares identity with monocyte-derived hepatocytestimulating factor and regulates the major acute phase protein response in liver cells. Proc. Natl. Acad. Sci., 84:7251-7255.

Hirano, T., Yasukawa, K., Harada, H., Taga, T., Watanabe, Y., Matsuda, T., Kashiwamura, S., Nakajima, K., Koyama, K., Iwamatsu, A., Tsunasawa, S., Sakiyama, F., Matsui, H., Takahara, Y., Taniguchi, T. and Kishimoto, T. 1986.Complementary DNA for a novel human interleukin (BSF-2) that induces B lymphocytes to produce immunoglobulin. Nature, 324: 73-76.

Houssiau, F.A., Coulie, P.G., Olive, D. and Van Snick, J. 1988. Synergistic activation of human $\mathrm{T}$ cells by interleukin-1 and interleukin-6. Eur. J. Immunol., 18: 653-656.

Ikebuchi, K., Wong, G.G., Clark, S.C., Ihle, J.N., Hirai, Y. and Ogawa, M. 1987.Interleukin-6 enhancement of interleukin-3 dependent proliferation of multipotential hemopoietic progenitors. Proc. Natl. Acad. Sci. USA., 84: 90359039.

Kaiser, P., Rothwell, L., Goodchild, M. and Bumstead, N. 2004. The chicken 
proinflammatory cytokines interleukin$1 \mathrm{~b}$ and interleukin-6: differences in gene structure and genetic location compared with their mammalian orthologues. Animal Genetics, 35: 169175.

Kishimoto, T., Akira, S., Narazaki, M. andTaga, T. 1995.Interleukin-6 family of cytokines and gp130.Blood, 86: 1243-1254.

Okada, M., Sakaguchi, N., Yoshimura, N., Hara, H., Shimizu, K., Yoshida, N., Yoshizaki, K., Kishimoto, S., Yamamura, Y., Kishimoto, T. 1983. Bcell growth factors and B-cell differentiation factor from human $\mathrm{T}$ hybridomas. Two distinct kinds of Bcell growth factor and their synergism in B-cell proliferation.J. Exp. Med., 157: 583-590.

Sambrook, J.E.,Fritschk, F. and Maniatis, T. 1989. Molecular cloning: a laboratory manual. 2nd ed., Cold spring Harbor
Laboratory Press, Cold Spring Harbor, N.Y. pp. 317-336.

Satoh, T., Nakamura, S., Taga, T., Matsuda, T., Hirano, T., Kishimoto, T. and Kaziro, Y. 1988. Induction of neuronal differentiation in PC12 cells by B-cell stimulatory factor $2 /$ interleukin- 6 . Mol. Cell Biol., 8: 3546-3549.

Schneider, K., Klaas, R., Kaspers, B. and Staeheli, P. 2001. Chicken interleukin-6 cDNA structure and biological properties. Eur. J. Biochem., 268: 42004206.

Weissenbach, J., Chernajovsky, Y., Zeevi, M., Shulman, L., Soreq, H., Nir, U., Wallach, D., Perricaudet, M., Tiollais, P. and Revel, M. 1980. Two interferon mRNAs in human fibroblasts: in vitro translation and Escherichia coli cloning studies. Proc. Natl. Acad. Sci. USA., 77: 7152-7156.

\section{How to cite this article:}

Goyal, G., V. Upmanyu, S. Shukla, S. Mehra, S. K. Singh, V. Tomar, S. K. Bhanja and Sharma, D. 2021. Genetic Relatedness among Guinea Fowl (Numida meleagris) and Other Poultry Species based on Sequence Homology in Interleukin-6 (IL-6) gene. Int.J.Curr.Microbiol.App.Sci. 10(01): 3414-3420. doi: https://doi.org/10.20546/ijcmas.2021.1001.402 